\title{
The Dilemma Of Investment Planning For Female Investors
}

Naveen Malhotra. Ph.D, Eckerd College, USA

Haley Crum, V.P., Frank Crum Staffing, USA

\begin{abstract}
Nothing gets Americans more excited than the discussion of which sex is more capable of securing superior investment returns. This paper challenges the commonly held belief that women are incapable of positioning themselves for financial stability. In most households, men typically are at the financial helm while women tend to other family responsibilities. Truth be known, women are equally capable of holding their own in the world of investment finance. It is just that they have not been given a chance. This paper delves into the impediments faced by women and how they can overcome them.
\end{abstract}

\section{INTRODUCTION}



inancial advisers have traditionally underserved women in the money management arena. With the ever increasing ranks of professional women in the work force, they ignore this tremendous client base at their own peril. They tend to water down their answers directed to their female customers in response to their queries often assuming that they aren't really interested in the full and complete answers anyway. It turns out that the female population really does want to learn, but they are just a little more fearful of the unknown, and less willing to invest on a whim without fully understanding what they're getting themselves into.

\section{EVOLUTION OF WOMEN INVESTORS}

It is that age old controversy that keeps resurfacing about men and women as to who handles money and investments better. Men tend to think that they have the upper hand and of course, women let them think so. The truth is that men and women are wired very differently and as a result, their investment temperaments differ. Due to the social rules and mores that have existed for centuries, women typically have not been recognized for their knowledge or skill. Men were the head of the household, the breadwinners, protectors, leaders and the "brains" in the family. Women were taught where their place was in the world, and how to properly care for the family unit by cooking, cleaning and raising children, and how to follow men's lead. They were never given the opportunity, until recent years, to really have a voice, much less manage their own funds to pave a way towards their financial stability for the future. Women haven't always been given the opportunity to handle money, but thanks to those free-spirited women along the way in America who spoke up for women's rights so they could be empowered to handle their future instead of depending on the male members of the family. Men should be relieved that they don't have to carry that responsibility anymore and renounce the long established common traditions.

Women's life expectancy far exceeds that of men, so they need to be earnestly concerned about their future financial well being. The women of yesteryear sought to gain more rights which have resulted in the most drastic changes in their professional lives. Today, more women than ever are receiving higher levels of educational achievement. An increasing number have taken the role as the primary breadwinners for their families. The earning power of young single women has surpassed that of their male peers in large American cities. An analysis of the Census Bureau data reveals that in 2008, single, childless women between the ages of 22 and 30 were earning $8 \%$ more than their male counterparts.

The number of late-life divorces continues to increase while the average age of widowhood is around sixty years of age. This leaves women to fend for themselves for an average of twenty-two years. It is this reality that has 
propelled women to get more involved in financial matters, and developing a plan for their financial security to be able to adequately provide for themselves in later life.

Today, the number of women responsible for their own investing continues to grow, even though men still make the lion's share of the choices about which stocks or mutual funds to invest in. Women are quickly closing the gap. Hutheesing (2010) states that, "North American women say they want equal access to information, and equal consideration". Today, women in the United States have a natural advantage in this regard over the women living in other countries that still have not recognized women's rights. In spite of the progress that has been made, the following statistics show rather sobering facts about the financial plight of women.

Only 5\% of Americans can afford to retire at age 65!" (Bach, 2002).

The average retirement income for a woman over 65 is less than $\$ 7000$ a year. (Bach, 2002)

Two-thirds of women over 65 rely on Social Security as their primary source of income. Consequently, women are twice as likely as men to live out their golden years at or below poverty levels. (Thakor, 2007)

Women need to keep in mind that their retirement careers can be longer than their working career. (Prince, 1996)

If a woman has $50 \%$ less service than a man, coupled with the fact she earns nearly 2/3rds of men's earnings means that a woman's retirement benefits will be one-fourth the size of her male colleagues. (Patterson, 1993)

On the whole, women suffer from wage gap when compared to men. They have less access to credit, interrupted careers due to child and family care, and have a longer life expectancy. (Malhotra \& Witt, 2010)

Only $12 \%$ of women make the investment decisions in their households...This is frightening when statistics also indicate $90 \%$ of all women will be solely responsible for their families' finances at some point in their lives. (Lee, 1996)

\section{PLIGHT OF WOMEN INVESTORS}

Women have several advantages over men which can allow them to lay a solid financial foundation when compared to men. Women aren't afraid to ask for directions but in turn they also expect to receive the proper guidance from their financial advisors when they ask for them. They want to receive the same financial information that men receive from investment professionals without it being dumbed down or diluted. Meeting with an advisor can often be a humiliating experience for women who want to build a long term professional relationship. Advisors still do not completely understand why women ask for investment advice or they would be serving them better.

The female gender values safety and like to feel comfortable with their financial decisions and advisors. For them investing is a deliberate and rational process. They are less likely to listen to the 'talking heads' on CNBC and make their decisions accordingly. Given their circumstances women realize that they have more to lose than men if they make a poor investment decisions. They buy what they like and what they know and are familiar with. In addition, they hold on to their investments for a longtime. Odean \& Barber (2001) concluded that men do worse than women as investors. The reason has to do with overconfidence and overtrading. Men trade $67 \%$ more often than women and end up with results before taxes of $1.4 \%$ a year behind women. Women tend to be less afflicted than men by overconfidence or the belief that they know more than they actually do. Academic research suggests that men think that they know what they're doing, even when the reality is different. Over confidence can hurt one's ultimate goal of financial well being.

New opinions are always suspected, and usually opposed. If for no other reason, then they are not already common. There's no telling when the feminist movement actually started, but it was probably prior to the documented start dating back to the mid-1800s. Women have probably always pushed for equality on all levels, but they were not granted a voice until someone decided to take a stand. What women have to realize is that nobody gives you power. You just make your own way and take it. Women have a balanced sense of realism and 
pragmatism which can help them become sound investors. Typically, women do not jump in uncharted territory when it comes to investing. They are more likely to acknowledge their own limits if they are unsure of something, unlike their male counterparts.

Traditionally, women have been ill served by the investment advisor community when seeking advice. A recent study released by The Boston Consulting Group (2010) states that women claim to receive "inferior versions of their [financial advisor's] standard offerings", while others say advisers for women are too quick to focus on strategies that don't emphasize performance, assuming that women are more inclined to make investment decisions based solely on social issues. The solution is for wealth managers to understand the differences between the needs of men and women clients and their relational styles. Women are often looking to fulfill long-term goals and want to receive personalized advice from their banking relationships. Showing empathy and building trust are critical.

Female investors are more deliberate in researching the specifics of investments and take their time in properly allocating and diversifying their funds within their portfolios. They are quite comfortable with their choices by the time they pull the trigger and purchase their investments. A Senior Vice President for Raymond James, who would prefer to remain anonymous, stated in an interview that "women are reluctant to get involved for what ever reason". But the reasons are quite obvious they have not been properly shown how to go about investing. Jennifer Lerner, a psychologist at Harvard University's John F. Kennedy School of Government states that, "[t]here's a general emotional difference between men and women as they perceive and take risks" (Zweig). Men tend to respond with anger versus fear. When a person is angry they tend to lunge forward without thinking of the consequences of their actions while experiencing that emotion. Women respond with fear which makes them more timid to make any rash decision.

Hopefully, the financial service industry will begin to seek women clientele to provide them with professional advice to enable them to take more control of their financial future. Men, on the other hand, are typically too proud to ask their peers for advice. They would rather maintain the perception that they are confident and fully capable to get the job done. Maybe, it's time for men to start taking a few tips from the women and begin to ask for professional assistance. Overconfidence and financial investing don't go hand in hand. On a very fundamental level, women relate to money differently than men. They value security and use alternative methods to gather information, compare risk versus reward more objectively. Personal attitudes about finances play a key role in defining a woman's retirement goals.

Women invest more frequently in fixed-income investments which are more stable in the long run. Their low turnover results in lower overall costs and ultimately, higher returns. However, men on the other hand, trade more often and to do so at the wrong times. Higher frequency in trading results in more room for error. Peter Lynch, of Fidelity Investments, even warns investors to beware of the common practice of "pulling out the flowers to water the weeds". Lynch believes that investors need to only buy what they understand, do their homework and to invest in the long run.

Women also tend to find comfort in numbers by conversing with peers on major decisions they're likely to make. Men tend to keep their financial decisions to themselves. Women are now beginning to form their own investment clubs in greater numbers. They are realizing remarkable success in their investment returns (Housley, 2001). Lynch states that "stock picking has become a dying art because people don't want to do the work - simply because they haven't been taught how". He also believes that anyone who dedicates a small amount of research by looking at companies available to invest in on the stock market can "outperform $95 \%$ of the paid experts who manage the mutual funds". Since women look for more of a comfort zone while looking for potential companies to invest in, they should do well following this advice.

\section{CONCLUSION}

On the whole, women have more to lose than men if they make a poor investment decision. Women's participation in the labor force is often sporadic thus undermining their ability to save a lot of money or to be vested in an employer provided defined benefit plan or an employer match in the defined contribution plans. On the other hand, Female life expectancy far exceeds men's, they need to fund a longer retirement. Although, only $6 \%$ of senior 
citizens in the United States live in poverty in retirement, the sobering fact is that $75 \%$ of those seniors are women (Malhotra \& Witt, 2010). Women's expenses during retirement especially for medical care also tend to be at least twice or higher than those of men (Center for Disease Control, 2008). An increase in late life divorces also places women in a bad place and impairs their financial future; especially if they expecting their partners to provide financial stability for them during retirement. Women need to find ways to look out for their best interests and not rely on the generosity of a spouse.

Women need to continue to obtain knowledge about investing so they can be sure to protect themselves in spite of being under served by the financial advisor community. The Boston Consulting Study states that many wealth managers either overlook women as a discrete and important group or else use superficial strategies to reach them. Women want the same attention, advice, terms, and deals that men get with advisors providing clear objective recommendations based on their goals and risk portfolios. However, from an early age women need to begin taking an active role in the household financial affairs. Men can certainly be helpful by encouraging their spouses and daughters to be responsible for fiscal issues in the family. Women must move their retirement savings needs to the top of their "to do" list and begin investing from the first day of their first job. Identifying financial goals early and setting a realistic strategic plan will go a long way to overcoming the challenges women face in financial planning.

\section{REFERENCES}

1. $\quad$ Bach. D. (2002). Smart Women Finish Rich. New York: Broadway Books.

2. $\quad$ Barnes, R. (2010) "Pick Stocks Like Peter Lynch."

〈http://www.investopedia.com/articles/stocks/06/PeterLynch.asp〉.3-30.

3. Center for Disease Control and Prevention. (2008 August). Costs of Falls Among Older Adults. Http

4. Danish, P., Kumar. M., Zakrzewski. A., \& Zhiglinskaya. N. (2010). Leveling the Playing Field. Boston Consulting Group.

5. Housley, K. (2001).Chicks Laying Nest Eggs: How 10 Skirts Beat the Pants off Wall Street...and How You Can, Too! New York: Crown Business.

6. Hutheesing, N. (2010). Business News Investment Advice - DailyFinance. $\langle$ http://www.dailyfinance.com/story/investing/>.

7. Jupiter, M. (1998). Savvy Investing for Women, Strategies from a Self-Made Wall Street Millionaire. Prentice Hall Press. NJ.

8. Lee, Barbara (1996). Financially Independent Woman, a Step-By-Step Guide to Successful Investing. Carol Publishing Group. NJ.

9. Malhotra, N. \& Witt. M. (2010). Determinants of Financial and Retirement Planning: A Female Perspective. Journal of Business \& Economics Research.

10. $\quad$ New York Times. (2010)"Money, Men, Women." Reprinted in St. Petersburg Times. St. Petersburg, Fl.

11. Odean. T., \& Barber, B. (2001) Boys Will be Boys: Gender, Overconfidence, and Common Stock Investments. Quarterly Journal of Economics.

12. Prep Project. Looking Ahead to Your Financial Future. Southampton, NY: National Center for Women and Retirement Research, Long Island University, Southampton Campus, 1988. Print.

13. Patterson, M. (1993). The Working Woman's Guide to Retirement Planning Saving and Investing Now for a Secure Future, New Jersey: Prentice Hall. pp. 4-26.

14. Prince, F. \& Pi, D. (1996). Every Woman's Guide to Investing, 11 Steps to Financial Independence and Security, California: Prima Publishing. pp. 5-19.

15. Anonymous. (2010) Raymond James and Associates. St. Petersburg, Fl. Telephone Interview.

16. Thakor, M. \& Kedar, S. (2007). On My Own Two Feet, Massachusetts: Adams Media.

17. Zweig, J. The Little Book of Safe Money: How to Conquer Killer Markets, Con Artists, and Yourself. Hoboken, NJ: Wiley, 2010. Print.

18. Zweig, J. (2009 May 9). For Mother's Day, Give Her Reins to the Portfolio. The Wall Street Journal. 